\title{
Comparison of meat products' composition bearing/not-bearing claims marketed in the Czech Republic
}

\author{
Pavla Steinhauserová ${ }^{1}$, Irena Řehůřková ${ }^{2}$, Jiř́i Ruprich ${ }^{1,2}$ \\ ${ }^{1}$ Department of Milk Hygiene and Technology, Faculty of Veterinary Hygiene and Ecology, \\ University of Veterinary and Pharmaceutical Sciences Brno, Czech Republic \\ ${ }^{2}$ National Institute of Public Health, Centre for Health, Nutrition and Food, Brno, Czech Republic
}

Received July 25, 2011

Accepted December 14, 2011

\begin{abstract}
The aim of this study was to analyse the occurrence and specific composition of meat products (MPs) bearing nutrition/health claims marketed in the Czech Republic. MPs were analysed for fat content, fatty acids (FA) composition and sodium (Na) content. The compliance with legal requirements (Regulation EC No 1924/2006) and information stated on the product was checked. This study is the first one in the Czech Republic dealing with this issue. Among hundreds of marketed MPs, we observed only a limited number of MPs bearing claims. We analysed and compared chemical composition of $12 \mathrm{MPs}$ bearing nutrition claims to 5 identical brand products without any claim. None of the claims dealt with reduced amount of $\mathrm{Na} /$ salt content and none was evaluated as an explicit health claim. Most of the mentioned nutrition claims were declared as "Fit, Fitness, Light, Wellness, With low/reduced fat". Only one claim mentioned " $\omega 3$ FA addition". All analytical results, except one product with claim "Low/reduced fat" or "Light" (if connected with fat reduction), corresponded to the legal requirements and information stated on the product. Three statements on the products associated with $\mathrm{Na}$ /salt content did not correspond to the amount measured in the sample. When comparing MPs "with" and "without" nutrition claim, lightly reduced fat or added amount of $\omega 3$ FA was recognized only in one product with claim. Other indicators, such as $\mathrm{Na}$ /salt content, better FA profile or more evident fat reduction were not found. The results of our study show that claims such as "Healthier, Fit, Fitness or Wellness" may be considered as somewhat misleading for consumers.
\end{abstract}

Food, fat, fatty acids, sodium, health

Meat has an important role in a healthy diet, providing protein with a good balance of amino-acids, beneficial forms of vitamins and essentials minerals (McAfee et al. 2010). However, processed meats are often associated with a high intake of fat, saturated fatty acids, cholesterol and sodium (Na) (Valsta et al. 2005; Decker et al. 2010). The importance of fat quantity and also of the fatty acids (FA) composition in human diet is expressed in a number of national and international nutritional recommendations (WHO 2003; EFSA 2010). Not only the FA group but also individual FA affect a wide range of metabolic functions in human body. An overall understanding of relationships between the intake and health risk is still limited. Some saturated FA raise blood concentrations of low density lipoprotein (LDL) cholesterol, which increases the risk of atherosclerosis leading to cardiovascular diseases while unsaturated FA lower it (Smit et al. 2009). A high $\mathrm{Na}$ intake, in food generally represented by sodium chloride $(\mathrm{NaCl})$, is one of major risk factors of hypertension resulting in coronary heart disease, stroke and renal disease (He et al. 2007). According to the European Food Safety Authority (EFSA), the European population's Na daily intake is 3-5 g which exceeds the daily dose recommended by WHO (2.0 g Na/person/day) or EFSA (1.5 g Na/person/day) (WHO 2003; EFSA 2006). The main source of $\mathrm{Na}$ in the diet is processed foods(70-75\%), wheremeat and MPs are the second major source of $\mathrm{Na}$ /salt following cereals and cereal products (SACN 2003). The estimated daily Na intake is above $2 \mathrm{~g}$ /day for more 
than $95 \%$ of Czech adults; between $10-20 \%$ is from meat and MPs (Ruprich et al. 2006). Many national and international organizations have set up targets for reduction of Na consumed in common diet (SACN 2003; WHO 2003). Consumers also demand healthier MPs with reduced contents of fat, cholesterol, salt, improved FA profile or incorporated health enhancing ingredients. Products bearing claims that are nowadays presented and studied beside traditional MPs may be perceived as having a nutritional or health advantage over similar MPs without these claims (Colmenero 2007; Zhang et al. 2010). A nutrition claim states that the food has particular beneficial nutritional properties due to energy, nutrients or other substances provided in reduced or increased proportions. A health claim states a relationship between the food, category or food constituents and consumer's health (Regulation EC No 1924/2006).

The aim of this study was to analyse the FA profile, fat and $\mathrm{Na}$ content in MPs bearing claims and identical MPs without these claims, in order to test the compliance with legal requirements and claims stated on the product. This study was carried out to determine whether the nutrition/health claims mask other nutritional properties of a product, which could mislead consumers trying to make healthy choices of a balanced diet.

\section{Materials and Methods}

A total of 17 samples were purchased from 6 major retail chains in the Czech Republic (July-September 2010). Five samples of MPs with nutrition/health claims on the product and the same 5 products without any claim, produced by the same manufacturer, were purchased to compare the FA profile, total fat and $\mathrm{Na}$ content. Additional 7 MPs bearing nutrition claims (without comparable counterpart = product from the same manufacturer but without claim) were analyzed. Samples were transported to the National Institute of Public Health - Centre for Health, Nutrition and Food in Brno to a laboratory accredited by the European Standard EN ISO/IEC 17025 for all necessary analytical methods. Samples were stored at $0-4{ }^{\circ} \mathrm{C}$ for $48 \mathrm{~h}$, homogenized by Grindomix (120 s, $3000 \mathrm{rpm})$ at room temperature and kept in plastic boxes at $-18{ }^{\circ} \mathrm{C}$ until the fat, $\mathrm{FA}$ and $\mathrm{Na}$ analysis.

Fat and FA analysis

Total lipids from $50 \mathrm{~g}$ of homogenized sample were extracted with $200 \mathrm{ml}$ of petroleum ether/acetone $(2: 1)$ by homogenization on Polytron PT-MR $3100(180 \mathrm{~s}, 10000 \mathrm{rpm})$ at room temperature.Triacylglycerols were after saponification and ester interchange with methanol detected as methylesters of FA. A total of 37 of FA methylesters (Standard Supelco 37 Component FAME Mix) were analysed using the method of gas chromatography on the TRACE GC chromatograph (ThermoQuest, Italy). The FA methylesters were separated on the capillary column Supelco SP $2560(100 \mathrm{~m} \times 0.25 \mathrm{~mm} \times 0.2 \mu \mathrm{m})$ and detected by flame-ionizing detection. For the data collection and processing, chromatographic software HP ChromQuest 3.0 was used.

\section{$\mathrm{Na}$ analysis}

Approximately $1 \mathrm{~g}$ of homogenised sample was mixed with $6 \mathrm{ml}$ of $\mathrm{HNO}_{3}$ and $1 \mathrm{ml}$ of hydrogen peroxide and underwent pressure decomposition in closed microwave system ETHOS (Milestone, Italy). Subsequently, accredited method of atomic emission spectrophotometry was used. After the sample digestion and blending with $0.2 \% \mathrm{KCl}$ (FIAS 400, Perkin-Elmer), it was fogged into the acetylene-air flame. The emission was measured on AAS 3300 Perkin-Elmer spectrometer at the wavelength of $589.6 \mathrm{~nm}$.

Results of analysed MPs were expressed as each of $37 \mathrm{FA}$ and Na content per $1 \mathrm{~kg}$ of edible part (= arithmetic mean value of 3 parallel measurements with the standard deviation calculated). Meat itself contains Na which naturally ranges from $50-70 \mathrm{mg} / 100 \mathrm{~g}$ (Desmond 2006). The amount of $2.54 \mathrm{~g} \mathrm{NaCl}$ is equivalent to $1 \mathrm{~g}$ of $\mathrm{Na}$ (SACN 2003). For the comparison of results, the $\mathrm{NaCl}$ content ( $\mathrm{g} / \mathrm{kg}$ of sample) was calculated as: amount of $\mathrm{Na}$ $(\mathrm{g} / \mathrm{kg})$ measured in the sample minus $0.7(\mathrm{~g} / \mathrm{kg}$ of Na naturally in meat) multiplied by 2.54 .

\section{Results}

All measured values of total fat, FA and $\mathrm{Na} /$ recalculated salt content are presented in Tables 1 and 2. Values for each FA were summarized by its saturation to the groups of SFA $(n=17)$, MUFA $(n=9)$, PUFA $(n=11)$ and their representation in the sample was calculated $(\%)$. The $\omega 3$ FA group comprises the sum of 4 FA $(18: 3 N 3,20: 3 N 3,20: 5 N 3$, $22: 6 \mathrm{~N} 3)$. The total fat content measured in the sample (\%) was compared to the amount of total FA calculated from the FA analysis ( $\mathrm{g} / \mathrm{kg}$ of sample) and it corresponded to each other. 
Table 1. Comparison of analytical results of 5 meat products bearing claims to 5 meat products without any claim based on Regulation EC No 1924/2006 and information provided on the product.

\begin{tabular}{|c|c|c|c|c|c|c|}
\hline \multirow{2}{*}{$\begin{array}{l}\text { Product name } \\
\text { /Product } \\
\text { group }\end{array}$} & \multirow[b]{2}{*}{$\begin{array}{l}\text { Claim stated on } \\
\text { the product }\end{array}$} & \multicolumn{4}{|c|}{ Analyzed indicators } & \multirow{2}{*}{$\begin{array}{l}{ }^{1} \text { Compliance/noncompliance with } \\
\text { European legislation } \\
\text { Regulation EC No 1924/2006 } \\
\text { and the information on the product }\end{array}$} \\
\hline & & $\begin{array}{l}\text { Fat } \\
(\%)\end{array}$ & $\begin{array}{l}\text { SFA/MUFA } \\
\text { /PUFA } \\
(\%)\end{array}$ & $\begin{array}{c}\omega 3 \\
\mathrm{FA} \\
(\mathrm{g} / \mathrm{kg})\end{array}$ & $\begin{array}{l}\mathrm{NaCl} \\
(\mathrm{g} / \mathrm{kg})\end{array}$ & \\
\hline $\begin{array}{l}\text { Tyrolian } \\
\text { ham Karé } \\
\text { Light } \\
\text { /Dried meat }\end{array}$ & $\begin{array}{l}\text { Light } \\
\text { Max. } 3 \% \text { fat } \\
\text { Max. } 4 \% \text { salt }\end{array}$ & 4.6 & $41 / 53 / 7$ & 0.12 & 41.9 & $\begin{array}{l}{ }^{2,3} \text { The fat reduction is } 76 \%=\text { corresponds to the regulation. } \\
\text { The amount of fat measured does not correspond } \\
\text { to max. fat on the label. Product contains } 4.2 \% \text { of salt } \\
=\text { does not correspond to the amount on the label. }\end{array}$ \\
\hline $\begin{array}{l}\text { Tyrolian } \\
\text { ham Karé } \\
\text { /Dried meat }\end{array}$ & $\begin{array}{l}\text { Max. } 24 \% \text { fat } \\
\mathrm{Na} / \mathrm{NaCl} \text { not } \\
\text { declared }\end{array}$ & 17.6 & $42 / 45 / 13$ & 1.15 & 50.8 & $\begin{array}{l}\text { The amount of fat measured in the product corresponds } \\
\text { to max. fat on the label. }\end{array}$ \\
\hline $\begin{array}{l}\text { Poličan } \\
\text { Fit } \\
\text { /Dry } \\
\text { fermented } \\
\text { sausage }\end{array}$ & $\begin{array}{l}\text { Healthier and Fit } \\
\omega 3 \text { FA added } \\
\text { Max. } 4.5 \% \text { salt }\end{array}$ & 33.4 & $40 / 47 / 13$ & 2.21 & 36.6 & $\begin{array}{l}{ }^{4} \text { The } \omega 3 \text { FA representation is } 16 \times \text { higher (more than } 30 \% \text { ) } \\
=\text { corresponds to the regulation (total amount is relatively low). } \\
\text { The amount of salt in the product corresponds to the amount } \\
\text { on the label. }\end{array}$ \\
\hline $\begin{array}{l}\text { Poličan } \\
\text { /Dry } \\
\text { fermented } \\
\text { sausage }\end{array}$ & Max. $50 \%$ fat & 34.4 & $41 / 48 / 12$ & 0.14 & 31.9 & $\begin{array}{l}\text { The amount of fat measured in the product corresponds } \\
\text { to max. fat on the label. } \\
\text { The amount of salt in the product corresponds } \\
\text { to the amount on the label. }\end{array}$ \\
\hline $\begin{array}{l}\text { Vysočina } \\
\text { Fit } \\
\text { /Salami }\end{array}$ & $\begin{array}{l}\text { Healthier and Fit } \\
\text { Reduced fat to } \\
25 \% \\
\text { Max. } 4.5 \% \text { salt }\end{array}$ & 20.1 & $42 / 46 / 12$ & 0.15 & 31.1 & $\begin{array}{l}{ }^{2} \text { The fat reduction is } 46 \%=\text { corresponds to the regulation. } \\
\text { Fat content corresponds to the amount on the label. } \\
\text { The amount of salt in the product corresponds to the amount } \\
\text { on the label. }\end{array}$ \\
\hline $\begin{array}{l}\text { Vysočina } \\
\text { /Salami }\end{array}$ & $\begin{array}{l}\text { Max. } 50 \% \text { fat } \\
\text { Max. } 4.5 \% \text { salt }\end{array}$ & 37.4 & $41 / 47 / 12$ & 1.84 & 28.8 & $\begin{array}{l}\text { The amount of fat measured in the sample corresponds } \\
\text { to max. fat on the label. The amount of salt in the product } \\
\text { corresponds to the amount on the label. }\end{array}$ \\
\hline $\begin{array}{l}\text { Chicken } \\
\text { breast ham } \\
\text { Fitness } \\
\text { /Cooked } \\
\text { product }\end{array}$ & $\begin{array}{l}\text { Fitness } \\
\text { Low fat content } \\
\text { Max. } 5 \% \text { fat } \\
\text { Max. } 2.8 \% \text { salt }\end{array}$ & 1.3 & $39 / 48 / 13$ & 0.00 & 18.7 & $\begin{array}{l}{ }^{5} \text { The fat content is not more than } 3 \%=\text { corresponds } \\
\text { to the regulation. The amount of fat corresponds } \\
\text { to max. fat on the label. The amount of salt in the product } \\
\text { corresponds to the amount on the label. }\end{array}$ \\
\hline $\begin{array}{l}\text { Chicken } \\
\text { breast ham } \\
\text { /Cooked } \\
\text { product }\end{array}$ & $\begin{array}{l}\text { Max. } 8 \% \text { fat } \\
\text { Max. } 2.8 \% \text { salt }\end{array}$ & 1.5 & $35 / 53 / 12$ & 0.12 & 20.7 & $\begin{array}{l}\text { The amount of fat measured in the product corresponds } \\
\text { product to max. fat on the label. The amount of salt in the } \\
\text { product corresponds to the amount on the label. }\end{array}$ \\
\hline Sausages & & & & & & \\
\hline $\begin{array}{l}\text { Fitness } \\
\text { Extra } \\
\text { /Cooked } \\
\text { product }\end{array}$ & $\begin{array}{l}\text { Fitness Extra } \\
\text { Max. } 15.8 \% \text { fat } \\
\text { Max. } 2.4 \% \text { salt }\end{array}$ & 12.3 & $42 / 49 / 10$ & 0.07 & 20.6 & $\begin{array}{l}{ }^{2} \text { The fat reduction is } 44 \%=\text { corresponds to the regulation. } \\
\text { The amount of fat corresponds to max. fat on the label. } \\
\text { The amount of salt in the product corresponds } \\
\text { to the amount on the label. }\end{array}$ \\
\hline $\begin{array}{l}\text { Sausages } \\
\text { /Cooked } \\
\text { product }\end{array}$ & $\begin{array}{l}\text { Max. } 35 \% \text { fat } \\
\text { Max. } 2.8 \% \text { salt }\end{array}$ & 21.9 & $42 / 48 / 11$ & 0.12 & 21.1 & $\begin{array}{l}\text { The amount of fat measured in the product corresponds } \\
\text { to max. fat on the label. The amount of salt in the product } \\
\text { corresponds to the amount on the label. }\end{array}$ \\
\hline
\end{tabular}

${ }^{1}$ An explanation of the claim's meaning according to the Regulation EC No 1924/2006:

${ }^{2}$ Reduced (name of the nutrient): the content of one or more nutrients has been reduced (or any claim likely to have the same meaning); only where the reduction content is at least $30 \%$ compared to a similar product

${ }^{3}$ Light/lite:this claim shall follow the same conditions as those set for the term "reduced" and shall be accompanied by an indication of the characteristic(s) which make(s) the food "light" or "lite" 
${ }^{4}$ Increased (name of the nutrient): the content of one or more nutrients, other than vitamins and minerals, has been increased (or and any claim likely to have the same meaning); only where the product meets the conditions for the claim "source of" and the increased content is at least $30 \%$ compared to a similar product

${ }^{5}$ Low fat: only where the product contains no more than $3 \mathrm{~g}$ of fat $/ 100 \mathrm{~g}$ for solids or $1.5 \mathrm{~g}$ of fat $/ 100 \mathrm{ml}$ for liquids

FA = fatty acids, $\mathrm{SFA}=$ saturated fatty acids, MUFA = monounsaturated fatty acids, PUFA = polyunsaturated fattyacids, $\omega 3 \mathrm{FA}=$ omega 3 fatty acids

Only 2 of 17 analysed MPs mentioned the information about $\mathrm{Na}$ content on the product. The amount of salt was stated on all except 2 of the analysed MPs.

\section{Discussion}

Most of mentioned nutrition claims on purchased MPs were declared as "Fit, Fitness, Light, Wellness, With low/reduced fat". Only one claim stated " $\omega 3$ FA addition". No MPs with the nutrition claim connected directly with a reduced $\mathrm{Na} / \mathrm{salt}$ content were found on the Czech market. Also, none of the MPs stated a clearly health claim. A claim mentioned as "Healthier" seems to be rather related to a nutrition claim connected with "fat reduction" and " $\omega 3$ FA addition" (Regulation EC No 1924/2006). Our results show that only the amount of fat measured in MPs with claims such as "Fit, Fitness or Wellness" was lower than in the product without this claim, and corresponded to the amount of fat declared on the product. However, when we took into account another important health indicator such as the FA composition, there was no benefit in consuming MPs bearing claims. Even 2 MPs without any claim had a better nutritional FA profile (less SFA and more unsaturated FA) than the same MPs declared as "Fit and Fitness". Moreover, the Na/salt content did not correspond to the amount declared on the product in 3 of 17 analyzed MPs. Typical Czech dry fermented salami Poličan declared as "Fit and Healthier, with $\omega 3$ FA addition" only had a higher $\omega 3$ FA content. The amount of total fat was almost the same ( $1 \%$ difference), and the $\mathrm{Na}$ /salt content was even higher in Poličan declared as "Fit" compared to a regular one without a claim. The same results of $\mathrm{Na}$ /salt content were observed in the salami Vysočina and Vysočina "Fit". Currently, there is no nutritional target proposed for $\mathrm{Na}$ /salt content in MPs in the Czech Republic. In the UK, the Food Standards Agency proposed targets of Na/ salt content at maximum $2.5 \mathrm{~g}$ salt $/ 1.4 \mathrm{~g}$ Na in $100 \mathrm{~g}$ of ham/cured meat and $1.4 \mathrm{~g}$ salt $/ 0.55 \mathrm{~g}$ $\mathrm{Na}$ in $100 \mathrm{~g}$ of sausages to be achieved by 2010 (FSA 2006). None of the 3 analyzed salami and 8 analyzed ham/treated products would met this recommendation; only 6 MPs would. All analytical results except 1 sample with the claim "Low/reduced fat" or "Light" (when connected with fat reduction) corresponded to the legislation requirement and the claim on the product.When comparing MPs "with" and "without" a nutrition claim, in reality, only lightly reduced fat in MPs and added amount of $\omega 3$ FA in one meat product with nutrition claims were recognized. Other indicators, such as $\mathrm{Na}$ /salt content, better FA profile or more evident fat reduction in these MPs were not found. From the nutritional point of view, claims such as "Healthier, Fit, Fitness or Wellness" may therefore be considered as somewhat misleading for consumers. In our opinion, such claims should secure more considerable nutritional benefits for the consumers than a minor fat reduction in comparison to the product without such claims. This would help people to make healthier choices of a balanced diet and lifestyle, and also increase the consumers' trust in the food safety and nutrition policy in EU countries.

\section{Acknowledgments}

This work was supported by the Internal Grant Agency, University of Veterinary and Pharmaceutical Sciences Brno; project IGA VFU 69/2010/FVHE. The authors would like to thank Ms. Sylva Saláková and Ms. Jana Řeháková for their assistance with chemical analyses. 
Table 2. Analytical results of 7 meat products bearing claims in comparison with the Regulation EC No $1924 / 2006$ and the information on the product

\begin{tabular}{|c|c|c|c|c|c|c|}
\hline \multirow{2}{*}{$\begin{array}{l}\text { Product name } \\
\text { /Product } \\
\text { group }\end{array}$} & \multirow[b]{2}{*}{$\begin{array}{l}\text { Claim stated on } \\
\text { the product }\end{array}$} & \multicolumn{4}{|c|}{ Analyzed indicators } & \multirow{2}{*}{$\begin{array}{l}{ }^{1} \text { Compliance/noncompliance with the } \\
\text { European legislation } \\
\text { Regulation EC No 1924/2006 } \\
\text { and the information on the product }\end{array}$} \\
\hline & & $\begin{array}{l}\text { Fat } \\
(\%)\end{array}$ & $\begin{array}{l}\text { SFA/MUFA } \\
\text { /PUFA } \\
(\%)\end{array}$ & $\begin{array}{c}\omega 3 \\
\mathrm{FA} \\
(\mathrm{g} / \mathrm{kg})\end{array}$ & $\begin{array}{l}\mathrm{NaCl} \\
(\mathrm{g} / \mathrm{kg})\end{array}$ & \\
\hline $\begin{array}{l}\text { Fitness } \\
\text { cooked } \\
\text { ham } \\
\text { /Cooked } \\
\text { product }\end{array}$ & $\begin{array}{l}\text { Fitness } \\
\text { Low fat } \\
(\max .5 \%) \\
\text { Sea salt } \\
(\max .2 .8 \%)\end{array}$ & 2.9 & $44 / 48 / 8$ & 0.00 & 26.1 & $\begin{array}{l}{ }^{5} \text { The fat content is not more than } 3 \%=\text { corresponds } \\
\text { to the regulation. The amount of fat corresponds } \\
\text { to max. fat on the label. Amount of salt in the product } \\
\text { corresponds to the amount on the label. }\end{array}$ \\
\hline $\begin{array}{l}\text { Cooked } \\
\text { ham } \\
\text { Junior } \\
\text { /Cooked } \\
\text { product }\end{array}$ & $\begin{array}{l}\text { Low fat } \\
(\max .3 \%) \\
\text { Salt } \\
(\max .2 .8 \%)\end{array}$ & 1.3 & $42 / 53 / 6$ & 0.01 & 23.3 & $\begin{array}{l}{ }^{5} \text { The fat content is not more than } 3 \%=\text { corresponds } \\
\text { to the regulation. The amount of fat corresponds } \\
\text { to max. fat on the label. The amount of salt in the product } \\
\text { corresponds to the amount on the label. }\end{array}$ \\
\hline $\begin{array}{l}\text { Chicken } \\
\text { sausages } \\
\text { natural } \\
\text { /Cooked } \\
\text { product }\end{array}$ & $\begin{array}{l}\text { Reduced fat } \\
(\max .10 \%) \\
\mathrm{Na} / \mathrm{NaCl} \\
\text { not declared }\end{array}$ & 7.1 & $35 / 49 / 16$ & 0.06 & 15.6 & $\begin{array}{l}{ }^{2} \text { The fat reduction is } 68 \%=\text { corresponds to the regulation } \\
\text { (compared to regular type of sausages). The amount } \\
\text { of fat measured corresponds to max. fat on the label. }\end{array}$ \\
\hline $\begin{array}{l}\text { Light Line } \\
\text { wellness } \\
\text { Ham } \\
\text { /Cooked } \\
\text { product }\end{array}$ & $\begin{array}{l}\text { Light wellness } \\
\text { Low fat } \\
(\max .3 \%) \\
\text { Salt } \\
(\max .2 .8 \%)\end{array}$ & 2.1 & $42 / 47 / 11$ & 0.07 & 45.9 & $\begin{array}{l}{ }^{5} \text { The fat content is not more than } 3 \%=\text { corresponds } \\
\text { to the regulation. The amount of fat corresponds } \\
\text { to max. fat on the label. } \\
\text { The amount of salt in the product does not correspond } \\
\text { to the amount on the label. }\end{array}$ \\
\hline $\begin{array}{l}\text { Ham } \\
\text { selection } \\
\text { for children } \\
\text { /Cooked } \\
\text { product }\end{array}$ & $\begin{array}{l}\text { Low fat } \\
\text { (max. 3\%) } \\
\text { Sea salt } \\
(\max .3 \%)\end{array}$ & 2.3 & $46 / 50 / 4$ & 0.05 & 22.2 & $\begin{array}{l}{ }^{5} \text { The fat content is not more than } 3 \%=\text { corresponds } \\
\text { to the regulation. The amount of fat corresponds } \\
\text { to max. fat on the label. The amount of salt in the product } \\
\text { corresponds to the amount on the label. }\end{array}$ \\
\hline $\begin{array}{l}\text { Light } \\
\text { wellness } \\
\text { ham } \\
\text { Top quality } \\
\text { /Cooked } \\
\text { product }\end{array}$ & $\begin{array}{l}\text { Light wellness } \\
\text { Fat }(\max .2 \%) \\
{ }^{6} \mathrm{SFA} \\
(0.8 \mathrm{~g} / 100 \mathrm{~g}) \\
\mathrm{Na}(0.4 \mathrm{~g} / 100 \mathrm{~g})\end{array}$ & 1.1 & $43 / 53 / 4$ & 0.02 & 23.9 & $\begin{array}{l}{ }^{2,3} \text { The fat reduction is } 45 \%=\text { corresponds to the regulation } \\
\text { (compared to regular type of ham). The amount of fat } \\
\text { measured corresponds to max. fat on the label. The }{ }^{6} \mathrm{SFA} \\
\text { content measured }(0.36 \mathrm{~g} / 100 \mathrm{~g}) \text { corresponds to the amount } \\
\text { on the label. The amount of } \mathrm{Na}(1.0 \mathrm{~g} / 100 \mathrm{~g}) \text { in the product } \\
\text { does not correspond to the amount on the label. }\end{array}$ \\
\hline $\begin{array}{l}\text { Wellness } \\
\text { extra } \\
\text { Junior } \\
\text { sausage } \\
\text { /Cooked } \\
\text { product }\end{array}$ & $\begin{array}{l}\text { Wellness extra } \\
\text { Fat }(\max .3 \%) \\
{ }^{6} \mathrm{SFA}(1 \mathrm{~g} / 100 \mathrm{~g}) \\
85 \% \text { less fat than } \\
\text { regular Junior } \\
\text { sausage } \\
\mathrm{Na}(1 \mathrm{~g} / 100 \mathrm{~g})\end{array}$ & 2.4 & $43 / 51 / 6$ & 0.07 & 22.1 & $\begin{array}{l}\text { The amount of fat measured in the product corresponds } \\
\text { to max. fat on the label. The SFA content measured } \\
(0.96 \mathrm{~g} / 100 \mathrm{~g}) \text { corresponds to the amount on the label. } \\
\text { The amount of } \mathrm{Na}(0.9 \mathrm{~g} / 100 \mathrm{~g}) \text { in the product corresponds } \\
\text { to the amount on the label. }\end{array}$ \\
\hline
\end{tabular}

${ }^{1}$ An explanation of the claim's meaning according to the Regulation EC No 1924/2006:

${ }^{2}$ Reduced (name of the nutrient): the content of one or more nutrients has been reduced (or any claim likely to have the same meaning); only where the reduction content is at least $30 \%$ compared to a similar product

${ }^{3}$ Light/lite: this claim shall follow the same conditions as those set for the term "reduced" and shall be accompanied by an indication of the characteristic(s) which make(s) the food "light" or "lite"

${ }^{4}$ Increased (name of the nutrient): the content of one or more nutrients, other than vitamins and minerals, has been increased (or and any claim likely to have the same meaning); only where the product meets the conditions for the claim "source of" and the increased content is at least $30 \%$ compared to a similar product

${ }^{5}$ Low fat: only where the product contains no more than $3 \mathrm{~g}$ of fat $/ 100 \mathrm{~g}$ for solids or $1.5 \mathrm{~g}$ of fat $/ 100 \mathrm{ml}$ for liquids

${ }^{6} \mathrm{FA}=$ fatty acids, $\mathrm{SFA}=$ saturated fatty acids, MUFA = monounsaturated fatty acids, $\mathrm{PUFA}=$ polyunsaturated fattyacids,

$\omega 3 \mathrm{FA}=$ omega 3 fatty acids 


\section{References}

Colmenero FJ 2007: Healthier lipid formulation approaches in meat-based functional foods. Technological options for replacement of meat fats by non-meat fats. Trends Food Sci Tech 18: 567-578

Decker EA, Park Y 2010: Healthier meat products as functional foods. Meat Sci 86: 49-55

Desmond E 2006: Reducing salt: A challenge for the meat industry. Meat Sci 74: 188-196

EFSA: Panel on dietetic products, nutrition, allergies, scientific opinion on dietary reference values for fats, including saturated fatty acids, polysaturated fatty acids, monosaturated fatty acids, trans fatty acids, and cholesterol. EFSA Journal 2010, 8:1461. [107 pp.]. doi:10.2903/j.efsa.2010.1461

EFSA Panel on dietetic products, nutrition, allergies, Tolerable upper intake levels for vitamins and minerals. EFSA, February 2006. ISBN: 92-9199-014-0.

FSA(Food Standards Agency), UK 2006. Available at: http://www.food.gov.uk/multimedia/pdfs/salttargetsapril06. pdf. Accessed July 14, 2011

He FJ, MacGregor GA 2007: Salt blood pressure and cardiovascular disease. Curr Opin Cardiol 22: 298-305

McAfee AJ, McSorley EM, Cuskelly GJ, Moss BM, Wallace JMW, Bonham MP, Fearon AM 2010: Red meat consumption: An overview of the risks and benefits. Meat Sci 84: 1-13

Regulation EC No 1924/2006 of the European Parliament and of the Council of 20 December 2006 on nutrition and health claims made on food. Official Journal of the European Union

Ruprich J, Dofkova M, Rehurkova I, Slaměníková E, Resová D 2006: Individual food consumption - the national study SISP04. CHFCH NIPH in Prague. Available at: http://www.chpr.szu.cz/spotrebapotravin.htm. Accessed July 22, 2011

SACN (Scientific Advisory Committee on Nutrition), Salt and Health.The Stationery Office 2003. ISBN: 0-11243075-9

Smit LA, Mozaffarian D, Willett W 2009: Review of fat and fatty acid requirements and criteria for developing dietary guidelines. Ann Nutr Metab 55: 44-55

Valsta LM, Tapanainen H, Männistö S 2005: Meat fats in nutrition. Meat Sci 70: 525-530

WHO/FAO (World Health Organisation/Food and Agriculture Organisation), 2003. Expert Report: Diet, nutrition and prevention of chronic diseases. Report of a Joint WHO/FAO Experts Consultation. WHO Technical Report Series 916. ISBN: 92-4-120-916-X

Zhang W, Xiao S, Samaraweera H, Lee EJ, Ahn DU 2010: Improving functional value of meat products. Meat Sci 86: 15-31 